\title{
What Is Evidence-Based Physiotherapy?
}

\author{
Mirella Veras, PhD, BScPT; Dahlia Kairy, PhD, pht; Nicole Paquet, PhD, pht ${ }^{\dagger}$
}

Evidence-based physiotherapy (EBP) is an emerging and increasing theme in rehabilitation and physiotherapy. Although it is increasingly used worldwide, a precise and appropriate definition has not been agreed on among clinicians and researchers.

The World Confederation for Physical Therapy (European region) has defined EBP as "a commitment to use the best available evidence to inform decision-making about the care of individuals that involves integrating physiotherapist practitioners and individual professional judgement with evidence gained through systematic research."1(p.1) This definition is based on Sackett and colleagues' definition of evidence-based medicine (EBM), published in 1996 by BMJ (formerly British Medical Journal). ${ }^{2}$

In 2000, Sackett and colleagues published a revised definition of EBM as "the integration of best research evidence with clinical expertise and patient values."3(p.1) This definition showed some progress because it now included research, clinical practice, and the values of the patient. However, it did not yet include all the elements that characterize EBM or EBP. For instance, it did not include ethical principles of autonomy, beneficence, non-maleficence, and justice, which are of utmost importance in evidence-based clinical decisions and go beyond patient values. Therefore, we propose defining EBP as follows: an area of study, research, and practice in which clinical decisions are based on the best available evidence, integrating professional practice and expertise with ethical principles. Although the terms study and research are often used as synonyms, for our purposes study (or knowledge acquisition) is defined as the act of devoting time to learning about any topic or area of knowledge. On one hand, to study is to learn a topic or some knowledge that has already been discovered and revealed; it can stimulate the eager to investigate, go deeper in their studies, and perhaps originate an innovation on existing knowledge; in this case, research skills would be needed to systematize the new knowledge and make it coherent and acceptable for the academic field. On the other hand, research (or knowledge creation) goes beyond the study of existing knowledge and requires a complex set of skills to develop new knowledge in a specific topic or field. There is an intrinsic connection between research and study, in that study is always part of research, but research, or the action of doing research, is not necessarily included in study. The reason for including both study and research as elements in our definition of EBP is to motivate critical thinking among physiotherapists, who should feel comfortable questioning the quality of the scientific evidence. In this way, physiotherapy professionals can be agents of transformation and participate in the production of science rather than merely be followers of new paradigms.

It is important to highlight EBP as a field of study and research in which physiotherapists can collect relevant information, use a variety of research methods to produce scientific evidence on topics related to patient evaluation and interventions in physiotherapy, and assess the quality of the scientific evidence already available. Several authors have criticized EBM methods, which they see as an attempt to monopolize science for standardizing methods and research tools around a unique scientific truth. ${ }^{4-6}$ Every health discipline should reflect on its practices and goals to construct a pertinent definition of evidence-based practice.

The arguments of these critics of EBM are supported mainly by the theories of Thomas Kuhn and Michel Foucault. Kuhn held that a scientific revolution occurs when a new paradigm - a theory or perspective that dominates the science and is generally accepted by all members of the scientific community-replaces an old paradigm, and two theories cannot coexist. Foucault's theory of epistemological ruptures in knowledge production follows a similar path. ${ }^{4-6}$

The fundamentals that support including clinical decision making based on the best available evidence and the integration of professional practice expertise with ethical principles (including, but not limited to, patient values) in the definition of EBP are already accepted in the Kuhnian sense of a paradigm that is scientifically accepted. The great vision of this integration is the recognition of evidence-based practice with a commitment to consider all the ethical pillars in clinical decisions so that the patient and society are included from beginning to end in the clinical decision-making process.

From the: *École de réadaptation, Université de Montréal, CRIR-site IRGLM du CIUSSS centre sud de l'lle de Montréal; †École des sciences de la réadaptation, Université d'Ottawa.

Correspondence to: Mirella Veras, École de réadaptation, Université de Montréal, 600 Rue Darling, Montréal, QC H1W 2V9; mvera025@uottawa.ca. 
Incorporating patients' values, beliefs, and preferences in clinical decisions is a challenge. The failure to include these components in clinical decisions has commonly received much criticism. However, to build a science or a practice based on evidence, we must go beyond the narrow walls of individual patients' values to consider all the ethical principles that should shape a fair and progressive clinical practice in contemporary society. Thus, clinicians might discuss evidence-based treatment options with their patients, thus opening the door to ethical discussions in which the benefits and risks of interventions are presented to patients so that they can participate in clinical decisions. ${ }^{7}$

\section{CONCLUSION}

Our definition of evidence-based physiotherapy contributes to a clarification of the term's meaning and scope. We have offered some arguments for including new elements to better define EBP as an area of study, research, and practice, adding the essential component of ethical principles. We welcome discussion and debate regarding this definition, with the ultimate goal of reaching some consensus on this important and emergent concept for the physiotherapy field.

\section{REFERENCES}

1. World Confederation for Physical Therapy-European Region. Evidence based physiotherapy [Internet]. Brussels: The Confederation; 2015. [cited 2015 Mar 24]. Available from: http://www.erwcpt.eu/ education/evidence_based_physiotherapy_evidence_and_research.

2. Sackett DL, Rosenberg WM, Gray JA, et al. Evidence based medicine: what it is and what it isn't. BMJ. 1996;312(7023):71-2. http:// dx.doi.org/10.1136/bmj.312.7023.71. Medline:8555924

3. Sackett DL, Strauss SE, Richardson WS. Evidence-based medicine: how to practice and teach EBM. London: Churchill-Livingstone; 2000 .

4. Holmes D, Murray SJ, Perron A, et al. Nursing best practice guidelines: reflecting on the obscene rise of the void. J Nurs Manag. 2008;16(4):394-403. http://dx.doi.org/10.1111/j.13652834.2008.00858.x. Medline:18405255

5. Samarkos MG. The philosophy of evidence-based medicine. Hosp Chronicles. 2006;1:27-35.

6. Solomon M. Just a paradigm: evidence-based medicine in epistemological context. Eur J Philos Sci. 2011;1(3):451-66. http:// dx.doi.org/10.1007/s13194-011-0034-6.

7. Hoffmann TC, Montori VM, Del Mar C. The connection between evidence-based medicine and shared decision making. JAMA. 2014;312(13):1295-6. http://dx.doi.org/10.1001/jama.2014.10186. Medline:25268434

DOI:10.3138/ptc.68.2.GEE

\title{
La physiothérapie fondée sur les données probantes : une définition
}

\author{
Mirella Veras, PhD, BScPT; Dahlia Kairy, PhD, pht; Nicole Paquet, PhD, pht ${ }^{\dagger}$
}

La physiothérapie fondée sur les données probantes (evidence-based physiotherapy, ou EBP) est une méthode de pratique qui prend de l'ampleur en réadaptation et en physiothérapie. Bien qu'elle soit de plus en plus adoptée partout dans le monde, il reste encore aux praticiens et aux chercheurs à formuler une définition précise et exacte.

La division européenne de la Confédération mondiale pour la thérapie physique (WCPT) définit l'EBP comme suit :

Engagement à fonder ses décisions de soins au patient sur les meilleures données probantes existantes en intégrant l'expérience des physiothérapeutes praticiens et leur avis professionnel aux données probantes issues de la recherche méthodique. ${ }^{1(\mathrm{p} .1)}$

Cette définition s'appuie sur la définition de la médecine fondée sur des données probantes (evidence-based medicine, ou EBM) publiée par Sackett et collaborateurs en 1996 dans la revue The BMJ (anciennement le British Medical Journal). ${ }^{2}$

En 2000, Sackett et collaborateurs ont publié une définition révisée de l'EBM, la décrivant comme l'« intégration des meilleures données issues de la recherche à l'expertise clinique et aux valeurs du patient ».3(p.1) Cette dernière définition marque un certain progrès, puisqu'elle réunit la recherche, la pratique clinique et les valeurs du patient. Il y manque encore cependant certains éléments caractérisant l'EBM ou l'EBP, à savoir notamment les principes éthiques d'autonomie, de bienfaisance, de nonmalveillance et de justice, lesquels transcendent les valeurs du patient et sont d'une importance critique dans la prise de décisions cliniques fondées sur des données probantes. Nous proposons donc de définir l'EBP comme « un champ d'étude, de recherche et de pratique dans le cadre duquel les décisions cliniques

\footnotetext{
* École de réadaptation, Université de Montréal, CRIR-site IRGLM du CIUSSS du Centre-Sud-de-I'Île-de-Montréal †École des sciences de la réadaptation, Université d'Ottawa.
}

Correspondance à : Mirella Veras, École de réadaptation, Université de Montréal, 600 Rue Darling, Montréal, QC H1W 2V9 ; mvera025@uottawa.ca. 